Jurnal Konstruksi Hukum | ISSN: XXXX | E-ISSN: XXXX Vol. 1, No. 1, September 2020 Hal. 145-151| Available online at https://www.ejournal.warmadewa.ac.id/index.php/jukonhum

DOI: https://doi.org/10.22225/jkh.1.1.2147.145-151

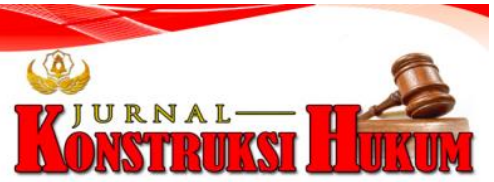

\title{
IMPLEMENTASI PRINSIP KEHATI-HATIAN (PRUDENTIAL) DALAM PEMBERIAN KREDIT PEMBIAYAAN KONSUMEN PADA PT. CLIPAN FINANCE INDONESIA TBK.
}

\author{
I Gede Agus Putrayasa, I Nyoman Putu Budiartha, Desak Gede Dwi Arini \\ Fakultas Hukum Universitas Warmadewa, Denpasar-Bali, Indonesia
}

\begin{abstract}
Abstrak
Indonesia adalah negara berkembang, dalam dekade terakhir ini mengalami kemajuan cukup pesat, walaupun kemajuan tersebut ditandai masa sulit karena baru saja bangkit dari krisis ekonomi yang berkepanjangan. Adapun tujuan penelitian ini untuk mengetahui bagaimana pelaksanaan prinsip kehati-hatian (prudential) dalam pemberian kredit pembiayaan konsumen di PT. Clipan Finance Indonesia Tbk. Dan tindakan apa yang dilakukan PT. Clipan Finance Indonesia Tbk. apabila terjadi keterlambatan pembayaran angsuran oleh konsumen sehingga menyebabkan kredit macet. Metode penelitian yang digunakan dalam penelitian ini adalah secara empiris dengan mencari informasi di PT. Clipan Finance Indonesia Tbk. Melalui wawancara yang di tambah dengan literatur yang terkait, yang kemudian diolah secara deskriptif kualitatif. Teknik pengumpulan data menggunakan sumber data primer (interview) dan sumber data sekunder (literatur). Hasil penelitian menunjukkan pelaksanaan prinsip prudential dalam pemberian kredit pembiayaan konsumen di PT. Clipan Finance Indonesia Tbk. adalah dengan menerapkan the five of credit atau $5 \mathrm{C}$ yaitu character, capacity, capital, collateral, dan conditions of economy, dimana dalam mengaplikasikan prinsip tersebut menerapkan dua metode dengan penggabungan metode pertimbangan dan metode empiris. Metode ini sepenuhnya menekankan keahlian analis kredit dalam menganalisis. Setelah mendapat pertimbangan analis kredit menyusun standar jumlah nilai evaluasi sesuai dengan pertimbangan-pertimbangan di atas untuk meluluskan atau menolak permintaan kredit. Tindakan-tindakan yang dilakukan PT. Clipan Finance Indonesia Tbk. apabila terjadi keterlambatan pembayaran angsuran sehingga menyebabkan kredit bermasalah/macet adalah PT. Clipan Finance Indonesia Tbk. akan memberikan surat peringatan dari I sampai III dengan tahapan tertentu, setelah tahapan tersebut tidak berhasil PT. Clipan Finance Indonesia Tbk. melakukan negoisasi dengan konsumen dan mencari jalan keluar terbaik.
\end{abstract}

Kata kunci: Pemberian kredit; Pembiayaan konsumen; Prinsip kehati-hatian

\begin{abstract}
Indonesia is a developing country, in the last decade it has progressed quite rapidly, even though this progress was marked by difficult times because it had just emerged from a prolonged economic crisis. The purpose of this study is to determine how the implementation of the principle of prudence (prudential) in providing consumer financing credit at PT. Clipan Finance Indonesia Tbk. And what actions are PT. Clipan Finance Indonesia Tbk. if there is a delay in installment payments by consumers, causing bad credit. The research method used in this research is empirically by looking for information at PT. Clipan Finance Indonesia Tbk. Through interviews with the addition of related literature, which is then processed descriptively qualitatively. Data collection techniques using primary data sources (interviews) and secondary data sources (literature). The results showed the implementation of the prudential principle in providing consumer financing credit at PT. Clipan Finance Indonesia Tbk. is to apply the five of credit or 5 Cs, namely character, capacity, capital, collateral, and conditions of economy, in which the application of these principles applies two methods by combining consideration and empirical methods. This method fully emphasizes the credit analyst's analytical expertise. After receiving consideration, the credit analyst prepares a standard amount of evaluation value according to the considerations above to pass or reject a credit request. Actions taken by PT. Clipan Finance Indonesia Tbk. if there is a delay in installment payments which causes problem / bad credit is PT. Clipan Finance Indonesia Tbk. will give warning letters from I to III with certain stages, after these stages are unsuccessful PT. Clipan Finance Indonesia Tbk. negotiate with consumers and find the best solution.
\end{abstract}

Keywords : Prudential principles; Credit extension; Consumer financing 


\section{PENDAHULUAN}

Kebutuhan masyarakat akan barang-barang keperluan rumah tangga dewasa ini sangat besar. Tapi dengan keadaan ekonomi seperti sekarang sangat sulit mendapatkan barang dengan kualitas terjamin dengan harga yang terjangkau (Sugiarto \& Subagio, 2014; Yasa, 2013). Di kota besar seperti kota Denpasar, cara yang paling tepat untuk memperoleh barang yang diinginkan tetapi belum mempunyai cukup uang untuk membeli barang secara tunai adalah dengan cara kredit. Salah satu cara membeli barang dengan cara kredit adalah melalui perusahaan pembiayaan atau lembaga pembiayaan non perbankan seperti Federal International Finance (FIF), Adira, SMS Finance, Clipan, WOM Finance, Kredit Plus, serta finance lainnya di kota Denpasar. Kegiatan ini disebut dengan pembiayaan konsumen, Misalnya jika ingin memiliki kendaraan bermotor tetapi belum mempunyai cukup uang untuk membeli secara tunai, maka untuk dapat memiliki kendaraan tersebut dengan cara kredit atau dengan kata lain dengan cara mengangsur dengan jangka waktu tertentu dengan dikenakan bunga pada suatu perusahaan pembiayaan.

Lembaga pembiayaan merupakan suatu bentuk usaha di bidang lembaga keuangan bukan bank yang mempunyai peran dalam pembiayaan (Dewianty, 2013; Wiwoho, 2014). Kegiatan ini dilakukan dengan menyediakan modal dana atau barang modal dengan tidak melakukan penarikan dana secara langsung dari masyarakat dengan dengan bentuk giro, deposito, tabungan dan surat sanggup bayar.

Berdasarkan kegiatan yang dilakukan oleh lembaga tersebut, lembaga pembiayaan mempunyai peran yang penting sebagai salah satu lembaga sumber pembiayaan alternatif yang potensial untuk menunjang pertumbuhan perekonomian nasional. Dikatakan sebagai sumber pembiayaan alternatif karena diluar lembaga pembiayaan masih banyak lembaga keuangan lain yang dapat memberi bantuan dana, seperti pegadaian, pasar modal, bank dan sebagainya. Tapi pada kenyataannya kebanyakan konsumen sulit mengakses dana dari setiap jenis sumber dana tersebut. Ini dikarenakan setiap lembaga keuangan ini menerapkan ketentuan yang tidak mudah dapat dipenuhi oleh konsumen. Lembaga pembiayaan secara umum dibedakan menjadi 2 yaitu: lembaga pembiayaan perbankan dan lembaga pembiayaan non perbankan (Prasetyawati, 2013). Timbulnya lembaga pembiayaan non perbankan ini dikarenakan melihat dari keadaan masyarakat yang sangat sulit memperoleh dana dari lembaga pembiayaan perbankan. Ini terjadi karena lembaga pembiayaan perbankan memiliki sistem dimana apabila seorang konsumen memiliki catatan kredit yang buruk disuatu bank maka tidak bisa memiliki akses lagi untuk mengajukan pinjaman maupun pembiayaan lagi. Selain itu kebanyakan masyarakat menilai dalam pengajuan pinjaman maupun pembiayaan pada lembaga perbankan harus melalui proses yang berbelit-belit dan syarat-syarat yang rumit. Kemajuan bidang teknologi telah memacu perusahaan untuk menghasilkan produk yang semakin canggih dan beragam. Kelebihan-kelebihan atas suatu produk terbaru mendorong masyarakat (konsumen) tertarik untuk membelinya meskipun secara finansial dana untuk membelinya tidak mecukupi. Ini merupakan suatu permasalahan tersendiri bagi masyarakat kelas menengah kebawah yang berpenghasilan tidak terlalu tinggi. Kondisi inilah yang menyebabkan berkembangnya lembaga pembiayaan konsumen sebagai salah satu sumber pembiayaan alternatif untuk memenuhi kebutuhan konsumen atas barangbarang konsumtif yang dibutuhkannya. Melalui pembiayaan konsumen, masyarakat yang tadinya kesulitan untuk membeli barang secara tunai, akan dapat teratasi dengan mudah dan cepat. Memberikan kredit merupakan pekerjaan sangat mudah, hampir semua orang dapat dengan mudah melakukannya. Namun untuk menarik kembali dana beserta bunga yang telah diberikan memerlukan keahlian, pengalaman, serta waktu dan biaya yang cukup besar. Kredit yang bermasalah maupun kredit yang macet mengganggu sendi kehidupan ekonomi, serta menurunkan kepercayaan masyarakat terhadap profesionalisme pengelolaan bisnis pembiayaan nasional.

Dalam hal ini sangat diperlukan analisa kredit dalam memberikan kredit pembiayaan konsumen. Analisa kredit merupakan salah satu kegiatan dari pemeriksaan, penelitian, dan analisa terhadap kelengkapan, keabsahan, dan kelayakan berkas/surat/data pemohon kredit calon konsumen hingga dikeluarkannya suatu keputusan apakah kredit tersebut diterima atau ditolak. Adapun yang dimaksud dengan analisa kredit adalah pekerjaan yang meliputi:

1. Mempersiapkan pekerjaan penguraian dari segala aspek, baik keuangan maupun non keuangan untuk mengetahui kemungkinan dapat/tidak dapat dipertimbangkannya suatu permohonan kredit. 
2. Menyusun laporan analisis yang diperlukan, yang berisi penguraian dan kesimpulan serta penyajian alternatif sebagai bahan pertimbangan untuk pengambilan keputusan pimpinan permohonan kredit nasabah.

Berdasarkan pendahuluan yang telah dipaparkan, maka dirumuskanlah beberapa hal yang menjadi permasalahan dalam penulisan ini.

Adapun permasalahan yang akan dibahas antara lain:

1. Bagaimana pelaksanaan prinsip kehati-hatian (prudential) dalampemberian kredit pembiayaan konsumen di PT. Clipan Finance Indonesia Tbk.?

2. Tindakan apa yang dilakukan PT. Clipan Finance Indonesia Tbk. apabila terjadi keterlambatan pembayaran angsuran oleh konsumen sehingga menyebabkan kredit macet?

\section{METODE PENELITIAN}

Penelitian ini menggunakan tipe penelitian empiris yang artinya pendekatan dengan aspek hukum dari hasil penelitian lapangan melalui data- data yang dikumpulkan melalui wawancara dan observasi (Soemitro, 1988). Hukum sebagai gejala sosiologis empiris dapat dipelajari di suatu sisi sebagai suatu independent variable yang menimbulkan efek pada berbagai kehidupan sosial, dan di sisi lain sebagai suatu independent variable yang muncul sebagai akibat berbagai ragam kekuatan dalam proses sosial. Jenis penelitian hukum yuridis yaitu berdasarkan peraturan-peraturan hukum yang ada kaitannya dengan masalah yang diteliti. Sedangkan jenis penelitian empiris yaitu berdasarkan atas kenyataan yang dihadapi yang ada pada tempat penelitian. Sumber data yang digunakan dalam penelitian ini berasal dari penelitian kepustakaan dan lapangan, dengan data utama yaitu data primer yang berasal dari penelitian lapangan, sedangkan hasil dari data kepustakaan adalah sebagai data penunjang dalam penelitian ini. Adapun sumber data tersebut dapat diperoleh melalui sumber data yaitu:

1. Data Primer (field research)

Data ini bersumber dari pengamatan langsung di lapangan dan diperoleh melalui penelitian di PT. Clipan Finance Indonesia Tbk. Alamat Jl. Gatot Subroto Timur, No. 126, Kesiman Petilan, Denpasar Timur, Kota Denpasar, Bali. Dengan cara mengadakan wawancara / melakukan penelitian langsung (interview) pada pihak yang terkait permasalahan.

2. Data sekunder (libraryresearch)

Data ini bersumber dari bahan Hukum primer yaitu, buku-buku, menganalisis dan menginterprestasikan pendapat atau ketentuan peraturan perundang-undangan dengan tujuan untuk mendapatkan landasan teoritis berupa pendapat dari para ahli yang berkaitan dengan penelitian ini. Berikutnya bahan hukum sekunder yaitu, literatur yang menyangkut pembahasan skripsi, jurnal hukum dan doktrin yang ada dalam buku. Dan terakhir bahan hukum tersier yaitu, bahan hukum yang memberikan petunjuk, penunjang ataupun penjelasan terhadap bahan hukum primer dan sekunder, contohnya: ensiklopedia, indeks kumulatif dan seterusnya (Mamuji, 2006).

Adapun metode yang dilakukan dengan jalan berkomunikasi langsung dengan subjek sebenarnya maupun dalam situasi buatan yaitu : pertama, pengumpulan data melalui studi kepustakaan, dalam pengumpulan data ini dari bahan bacaan yang ada hubungannya dengan permasalahan yang ada, bahan tersebut berupa buku pedoman, teori maupun peraturan yang ada hubungannya dalam masalah tersebut di atas. Kedua Pengumpulan data melalui wawancara, dalam metode ini wawancara diusahakan terlebih dahulu menyiapkan daftar pertanyaan dan pengembangan pertanyaan berikutnya tergantung situasi pada saat wawancara sedang berlangsung diusahakan sasaran yang diwawancara tersebut adalah orang yang kompeten di bidangnya agar dapat terkumpul sesuai dengan permasalahan sedang dibahas.

Setelah data terkumpul, kemudian diolah dan dianalisis secara kualitatif selanjutnya dari hasil pengolahan dan analisis data ini kemudian disajikan dengan cara deskriptif analisis. Artinya semua data yang terkumpul baik hasil penelitian kepustakaan atau hasil penelitian lapangan dipaparkan dan disertai analisis dengan menggunakan ketentuan hukum yang berlaku untuk mendapatkan kesimpulan sebagai akhir penulisan ini. 


\section{HASIL DAN PEMBAHASAN}

Berdasarkan penjelasan diatas, adapun permasalahan yang akan dibahas pada penelitian ini yaitu bagaimana pelaksanaan prinsip kehati-hatian (prudential) dalampemberian kredit pembiayaan konsumen di PT. Clipan Finance Indonesia Tbk. Serta tindakan apa yang dilakukan PT. Clipan Finance Indonesia Tbk. apabila terjadi keterlambatan pembayaran angsuran oleh konsumen sehingga menyebabkan kredit macet.

\section{Pelaksanaan Prinsip Kehati-Hatian (Prudential) dalam Pemberian Kredit Pembiayaan Konsumen di PT. Clipan Finance Indonesia Tbk.}

Dalam praktik perbankan dikenal adanya prinsip kehati-hatian yang digunakan dalam pemberian kredit kepada pihak kreditur. Prinsip kehati-hatian adalah suatu asas atau prinsip yang menyatakan bahwa bank dalam menjalankan fungsi dan kegiatan usahanya wajib bersikap hati-hati dalam rangka melindungi dana masyarakat yang dipercaya padanya. Prinsip ini diatur dalam Undangundang Perbankan Nomor 10 Tahun 1998, diatur dalam beberapa pasal, selain itu pengaturan prinsip ini juga ada pada SK Dir BI Nomor 27/162/KEP/DIR tanggal 31 Maret 1995. Berdasarkan SK Dir BI tersebut, Bank Umum wajib memiliki kebijakan perkreditan bank secara tertulis yang disetujui oleh dewan komisaris bank dengan sekurang-kurangnya memuat dan mengatur halhal pokok sebagai berikut: prinsip kehati-hatian dalam perkreditan, organisasi dan manajemen perkreditan, kebijakan persetujuan kredit, dokumentasi dan administrasi kredit, pengawasan kredit, dan penyelesaian kredit bermasalah. Dalam prakteknya, walaupun prinsip kehati-hatian tidak diatur secara khusus dalam dunia pembiayaan, namun banyak pelaku usaha pembiayaan mengadaptasi prinsip ini. Sampai saat ini PT. Clipan Finance Indonesia Tbk. dalam menganalisis calon konsumennya, kredit analis harus berpedoman pada $5 \mathrm{C}$, yang meliputi:

1. Character, Nasabah dengan record pembayaran yang sangat bagus.

2. Capacity, PT Auto bagus adalah usaha penyewaan kendaraan di beberapa instansi swasta, maskapi penerbangan, hotel dan lain-lain.

3. Capital, usaha milik pribadi dan saat ini disupport oleh 400 unit armada pendukung.

4. Collateral, 1 buah BPKB asli Toyota Avanza E tahun 2009, 3 buah BPKB asli

Toyota Avanza G tahun 2009, 1 buah kijang Innova G tahun 2009, 1 buah BPKB asli Daihatsu terios TX tahun 2009.

5. Condition, Income cukup untuk mengcover rental.

Fungsi jaminan dalam kasus kredit pembiayaan konsumen adalah sumber dana untuk melunasi kredit pinjaman. Keabsahan kepemilikan harta yang diagunkan oleh konsumen harus diteliti terlebih dahulu sebelum diterima sebagai jaminan kredit. Harga tersebut juga harus ditaksir nilainya. Kemudian dibandingkan dengan jumlah kredit yang diminta. Analisa kredit pembiayaan konsumen lebih menitikberatkan keberhasilan evaluasi pada keahlian dan pengalaman para analisis PT. Clipan Finance Indonesia Tbk. dalam menilai kemampuan dan kesediaan calon konsumen dalam membayar kembali kredit yang dipinjam. Untuk memperkirakan pembayaran di masa depan secara akurat, mengevaluasi prospek bisnis perusahaan maupun laporan keuangan sangatlah penting. Evaluasi atas prospek bisnis merupakan sasaran utama analisis lingkungan bisnis dan strategi (Wild, 2010). Kesan tentang watak calon konsumen dapat diperoleh dengan jalan mengevaluasi data pribadi termasuk tingkah laku, riwayat hidup, pekerjaan, tempat tinggal serta keadaan di sekitarnya. Apabila calon konsumen pernah bekerja pada lebih dari satu dari pekerjaan tetap, perlu dipelajari masa kerja pada tiap pekerjaan serta jabatan yang pernah dipegang. Masa kerja seseorang pada sebuah pekerjaan serta jabatan yang pernah dipegang, dapat menggambarkan besarnya kepercayaan yang pernah diberikan oleh pihak ketiga. Dengan demikian, daerah dan tempat tinggal dapat memberi kesan tentang watak seseorang.

Sumber utama dana pembayaran kembali kredit adalah penghasilan tetap calon konsumen. Agar dapat memperoleh gambaran tentang stabilitas penerimaan penghasilan, perlu diketahui pula apakah organisasi tempat calon konsumen bekerja bisa diandalkan kelangsungan hidupnya, minimal sampai jangka waktu kredit usai. Kemampuan calon konsumen mencicil kredit yang dipinjam, dapat diukur dengan jalan membandingkan jumlah penghasilan tetap konsumen dengan jumlah kewajiban keuangan tiap bulan. Secara singkat, perbandingan tadi dapat dihitung dengan mempergunakan rasio utang berbanding pendapatan atau debt to income ratio. Adapun rumus ratio utang berbanding pendapatan adalah Pengeluaran Tetap/bulan: Pendapatan Tetap/bulan. Selain itu menurut bapak 
Nyoman Agus Partika, Credit Analist PT. Clipan Finance Indonesia Tbk., akan menyusun standar jumlah nilai evaluasi (standard credit scoring) yang dipergunakan sebagai dasar pertimbangan untuk meluluskan atau menolak permintaan kredit yang diajukan. Standar nilai tersebut disusun dari gabungan hasil evaluasi berbagai macam kriteria yang dapat mempengaruhi kemampuan dan kesediaan konsumen melunasi kredit yang diterima. (Wawancara tanggal 17 Mei 2019).

\section{Tindakan PT. Clipan Finance Indonesia Tbk. apabila Terjadi Keterlambatan Pembayaran Angsuran oleh Konsumen sehingga menyebabkan Kredit Macet.}

Dalam pemberian kreditnya, PT. Clipan Finance Indonesia Tbk. melakukan perjanjian tertulis dengan calon konsumen, biasanya perjanjian ini disahkan di bawah tangan. Perjanjian akan berlaku ketika kedua belah pihak menandatangani perjanjian tersebut dan berakhir sampai dengan jangka waktu yang telah ditetapkan antara PT. Clipan Finance Indonesia Tbk. dengan calon konsumen. Pencairan fasilitas pembiayaan hanya bisa dilakukan setelah konsumen dan supplier memenuhi kewajibannya. Sedangkan tata cara penutupan pertanggungjawaban secara otomatis, kredit-kredit yang telah direalisasikan oleh Bank sepanjang memenuhi ketentuan yang disepakati bersama, secara langsung ditutup pertanggungjawabannya (Hadori, 1996). Salah satu bentuk jaminan yang lazim digunakan adalah jaminan fidusia atas kendaraan bermotor, dengan syarat jaminan tersebut harus jelas, yaitu dengan melihat nama yang tertera pada bukti kepemilikan kendaraan bermotor. Apabila konsumen lalai dalam melaksanakan kewajibannya, barang yang telah dijaminkan oleh konsumen kepada kreditur dapat dilakukan pelelangan untuk melunasi hutang konsumen. Bila mana konsumen tidak melunasi kewajibannya terhadap PT. Clipan Finance Indonesia Tbk. berdasarkan perjanjian kredit tersebut, maka PT. Clipan Finance Indonesia Tbk. berhak dan dengan ini diberi kuasa dengan hak subtitusi oleh konsumen untuk mengambil dimanapun dan ditempat siapapun objek kredit berada. PT. Clipan Finance Indonesia Tbk. kemudian menjualnya di muka umum atau secara dibawah tangan dengan perantara pihak lain dengan harga pasar yang layak dan dengan syarat serta ketentuan yang dianggap baik oleh PT. Clipan Finance Indonesia Tbk.

Lebih lanjut lagi disampaikan oleh Bapak Nyoman Suastika Manajer PT. Clipan Finance Indonesia Tbk, pada waktu PT. Clipan Finance Indonesia Tbk. menjalankan hak-hak istimewanya berdasarkan jaminan yang diberikan konsumen ini, maka semua hasil penjualan yang diterima dari pelaksanaan eksekusi jaminan akan diperhitungkan dengan seluruh kewajiban konsumen yang terhutang kepada PT. Clipan Finance Indonesia Tbk. sampai dengan saat penjualan objek kredit (jaminan), dengan tidak mengurangi hak PT. Clipan Finance Indonesia Tbk. apabila hasil penjualan objek kredit tersebut ternyata tidak cukup untuk melunasi seluruh kewajiban konsumen. Bila objek kredit yang sedang dijaminkan ini musnah, hilang, objek kredit dalam sengketa atau menurut taksiran PT. Clipan Finance Indonesia Tbk. objek kredit tersebut nilainya tidak sesuai lagi dengan kewajiban-kewajiban konsumen, maka PT. Clipan Finance Indonesia Tbk. berhak untuk meminta konsumen mengganti dengan barang yang lain untuk dijadikan jaminan pengganti. Kejadian ini tidak akan mengurangi atau menghapuskan kewajiban-kewajiban konsumen kepada PT. Clipan Finance Indonesia Tbk. Apabila konsumen tidak bersedia memberikan jaminan pengganti, maka konsumen wajib melunasi kewajibannya (hutang) kepada PT. Clipan Finance Indonesia Tbk., baik berupa kewajiban yang telah dan akan jatuh tempo, secara sekaligus dan seketika. (Wawancara tanggal 13 Mei 2019). Dalam hal ini menurut hukum jual beli dan peralihan hak usaha sempurna terjadi, sementara cicilan belum dibayar menjadi hutang piutang belaka (Fuady, 2005) . Menurut I Komang Ardika, AR Head PT. Clipan Finance Indonesia Tbk., dalam prakteknya menggolongkan suatu kredit dalam kriteria kredit bermasalah adalah sebagai berikut:

1. Konsumen menunggak pembayaran angsuran beserta bunganya lebih dari 7 hari tanpa ada kejelasan tertentu: (surat peringatan I)

2. Konsumen menunggak pembayaran angsuran beserta bunganya sampai 18 hari tanpa ada kejelasan tertentu: (surat peringatan II)

3. Konsumen menunggak pembayaran angsuran beserta bunganya sampai 30 hari tanpa ada kejelasan tertentu: (peringatan dari problem account officer)

4. Tidak ada itikad baik dari konsumen dalam hal penunggakan angsuran melebihi 30, maka atasan PT. Clipan Finance Indonesia Tbk turun tangan mencari jalan yang terbaik untuk menyelesaikan permasalahannya. (Wawancara tanggal 22 Mei 2019). 
Secara umum penyelesaian kredit bermasalah dilakukan dengan cara litigasi maupun non litigasi. Manajer harus mengevaluasi dampak keputusan keuangan dan kebijakan deviden terhadap nilai perusahaan. Lebih lanjut lagi disampaikan oleh Bapak Nyoman Suastika Manajer PT. Clipan Finance Indonesia Tbk. dalam prakteknya menyelesaikan kredit bermasalah/macet menggunakancara negoisasi, dengan permusyawarahan antara PT. Clipan Finance Indonesia Tbk. dengan konsumen, dan sampai sekarangpun melalui negoisasi penyelesaian kredit bermasalah dapat diselesaikan dengan baik. Sehingga tidak perlu sampai membawa permasalahan ke jalur peradilan maupun melalui jalur arbitrase (Wawancara tanggal 13 Mei 2019).

Untuk setiap hari keterlambatan pembayaran yang dilakukan konsumen kepada PT. Clipan Finance Indonesia Tbk. atas angsuran atau kewajiban- kewajiban lain yang ditetapkan dalam perjanjian, konsumen wajib membayar denda keterlambatan $0,4 \%$ per hari dari jumlah yang seharusnya dibayar, berdasarkan perhitungan satu tahun adalah 360 hari. Hal itu bisa berarti jumlah yang tercantum dalam polis bukan merupakan jumlah yang dibayar, tetapi menyatakan batas maksimum. Lebih lanjut lagi disampaikan oleh Bapak Nyoman Suastika Area Manajer PT. Clipan Finance Indonesia Tbk., dalam hal keterlambatan pembayaran angsuran, konsumen yang menunggak sampai 7 hari akan diberikan surat peringatan I (SP I) oleh PT. Clipan Finance Indonesia Tbk. Surat peringatan ini berisikan tentang angsuran yang jatuh tempo dan besarnya angsuran yang harus dibayar konsumen beserta dengan dendanya dan apabila konsumen menunda pembayaran angsuran maka denda keterlambatan akan bertambah sesuai dengan jumlah hari keterlambatan. Konsumen yang menunggak lebih dari 7 hari sampai 18 hari akan diberikan SP II. Isi dari SP II ini tidak berbeda dengan SP I yaitu memberitahukan agar konsumen melunasi angsuran yang tertunggak beserta denda keterlambatan. Apabila konsumen menunggak lebih dari itu sampai 30 hari. PT. Clipan Finance Indonesia Tbk. akan memberikan SP III. Konsumen yang menunggak melebihi itu (lebih dari 30 hari) akan diberikan surat konfirmasi yang menyatakan bahwa objek kredit akan ditarik kembali oleh PT. Clipan Finance Indonesia Tbk. apabila konsumen tidak segera melunasi tunggakannya sesuai dengan perjanjian yang telah disepakati bersama. Setelah satu minggu pemberian surat konfirmasi dan tidak ada itikad baik dari konsumen maupun jawaban yang pasti atau pelunasan tunggakan maka PT. Clipan Finance Indonesia Tbk. atau kuasanya akan menarik objek kredit dan menjualnya kembali di muka umum sesuai dengan perjanjian pembiayaan konsumen antara PT. Clipan Finance Indonesia Tbk. dengan konsumen.

\section{SIMPULAN DAN SARAN}

\section{Simpulan}

Berdasarkan hasil penelitian yang telah dilakukan, maka dapat diambil suatu simpulan yang sekaligus merupakan jawaban dari rumusan masalah adalah sebagai berikut:

a. Pelaksanaan prinsip kehati-hatian PT. Clipan Finance Indonesia Tbk. harus dapat menjaga likuiditas dan solvabilitas. Solvabilitas PT. Clipan Finance Indonesia Tbk. tergantung juga pada kemampuan masing-masing nasabahnya. Jadi disinilah peran analis kredit dalam memberikan kredit, apakah calon konsumen tersebut dapat dipercaya dan juga diandalkan.

b. Tindakan-tindakan yang dilakukan PT. Clipan Finance Indonesia Tbk. apabila terjadi keterlambatan pembayaran angsuran sehingga menyebabkan kredit bermasalah/macet adalah PT. Clipan Finance Indonesia Tbk. akan memberikan surat peringatan dari I sampai III dengan jangka waktu yang telah ditentukan, setelah tahapan tersebut tidak berhasil PT. Clipan Finance Indonesia Tbk. melakukan negoisasi dengan konsumen dan mencari jalan keluar yang terbaik. Dalam hal ini PT. Clipan Finance Indonesia Tbk. tidak pernah membawa kasus kredit macet sampai ke meja pengadilan karena menghabiskan biaya yang besar apabila penyelesaian dengan negoisasi tidak digubris oleh konsumen maka dilakukan penarikan objek kredit dan pelelangan.

c. Tanggung jawab analisis kredit pembiayaan konsumen di PT. Clipan adalah dengan menerapkan the five of credit atau $5 \mathrm{C}$ yaitu character, capacity, capital, collateral, dan condition of economy, dimana dalam mengaplikasikan prinsip tersebut dalam menganalisis permohonan kredit yang masuk menggunakan dua metode dengan menggabungkannya yaitu, metode pertimbangan dan metode empiris. Penggabungan ini dilakukan dengan mempertimbangkan karakter calon konsumen, rencana penggunaan kredit, sumber utama dana 
pembayaran pinjaman dan jaminan yang disediakan oleh calon konsumen, metode ini sepenuhnya menekankan keahlian analis kredit dalam menganalisis. Setelah mendapat pertimbangan analis kredit menyusun standar jumlah nilai evaluasi sesuai dengan pertimbangan-pertimbangan di atas untuk meluluskan atau menolak permintaan kredit.

\section{Saran}

Yang pertama pemerintah diharapkan membuat suatu peraturan perundang-undangan mengenai lembaga pembiayaan yang berdiri sendiri dimana peraturan tersebut juga mencakup tentang prinsip pemberian kredit maupun penyelesainnya, agar perusahaan-perusahaan pembiayaan tidak menggunakan peraturan perbankan dalam praktek pembiayaannya secara diam-diam, karena lembaga pembiayaan maupun perusahaan pembiayaan bukan termasuk lembaga perbankan. Kedua PT. Clipan Finance Indonesia Tbk. diharapkan dapat memiliki sumber daya manusia yang ahli dalam menganalisis calon konsumen dan menerapkan prinsip prudential dengan benar untuk mengurangi kredit bermasalah.

\section{DAFTAR PUSTAKA}

Dewianty, S. (2013). Sistem Lembaga Keuangan Shari'ah. Jurnal Ekonomi Dan Hukum Islam, 3(2), 94-116.

Fuady, M. (2005). Pengantar Hukum Bisnis. Citra Aditya Bakti.

Hadori, K. (1996). Penyelesaian Kredit Bermasalah melalui BUPLN. Sinar Grafika.

Mamuji, S. S. dan S. (2006). Penelitian Hukum Normatif. Raja Grafindo Persada.

Prasetyawati, E. (2013). Konsep Hukum Pembiayaan Konsumen di Masa yang akan Datang. Yustisia Jurnal Hukum, 2(2).

Soemitro, R. H. (1988). Metode Penelitian Hukum. Ghalian Indonesia.

Sugiarto, B. U., \& Subagio, H. (2014). Analisa Pengaruh Produk, Kualitas Pelayanan, Harga, Dan Store Atmosphere Terhadap Minat Beli Di Dream Of Khayangan Art Resto Surabaya. Jurnal Manajemen Pemasaran Petra, 2(1), 1-14.

Wild, K. . S. dan J. J. (2010). Analisis Laporan Keuangan. Salemba Empat.

Wiwoho, J. (2014). Distribusi Keadilan Bagi Masyarakat. Hukum Perbankan Indonesia, 43(1), 87-97.

Yasa, I. A. Ma. S. P. dan I. N. M. (2013). Faktor-Faktor yang Mempengaruhi Keputusan Oleh-Oleh Modern ( Studi Kasus Di Kota Denpasar ) I Nyoman Mahaendra Yasa Jurusan Ekonomi Pembangunan Fakultas Ekonomi Universitas Udayana Proses pembangunan merupakan suatu perubahan sosial budaya . Pembangunan s. E-Jurnal EP Unud, 2(5), 244-253. 